\title{
Intrathecal synthesis of anti-mycobacterial antibodies in patients with tuberculous meningitis. An immunoblotting study
}

\author{
C J M Sindic, D Boucquey, M P Van Antwerpen, M C Baelden, C Laterre, C Cocito
}

\begin{abstract}
Cerebrospinal fluid (CSF) and serum samples from eight patients with bacteriologically proven (6) or clinically suspected (2) tuberculous meningitis were tested for the presence of anti-mycobacterial IgG antibodies by an affinity-mediated immunoblot technique. This technique is based on agarose gel isoelectric focusing of paired CSF and serum samples diluted to the same IgG concentration, and transfer of the specific IgG antibodies onto mycobacterial antigen-loaded nitrocellulose sheets. An intrathecal synthesis of anti-mycobacterial oligoclonal IgG antibodies, often superimposed on diffuse polyclonal production was shown in all patients but not in patients with tension headache or other neurological disorders. Similar results were obtained when a purified mycobacterial antigen, A60, was used for coating the nitrocellulose sheets in place of a whole mycobacterial homogenate, indicating that A60 was a major immunogen. The number of anti-mycobacterial oligoclonal IgG bands increased with time, and persisted for years even in clinically cured patients. Some IgG bands had no detectable anti-mycobacterial activity, at least with the antigens preparations used in this study. The demonstration of such anti-mycobacterial IgG bands in he CSF could be a useful adjunct for the diagnosis of tuberculous meningitis, especially in the case of negative cultures.
\end{abstract}

Laboratoire de Neurochimie et Service de Neurologie, Université Catholique de Louvain, Brussels,

Belgium

C J M Sindic

D Boucquey

M P Van Antwerpen

C Laterre

Microbiology and Genetics Unit, Institute of Cellular Pathology, Brussels, Belgium

M C Baelden

C Cocito

Correspondence to:

C J M Sindic, Laboratoire de Neurochimie, UCI, 53-59,

Avenue Mounier, 1200 Brussels, Belgium.

Received 11 September 1989 and in revised form

11 December 1989

Accepted 3 January 1990

Despite a decline in the incidence of tuberculosis in western countries, ${ }^{1}$ tuberculous meningitis (TM) has not diminished in proportion and remains a serious illness with fatal consequences, if untreated. ${ }^{2}$ The rate and extent of recovery are related, in part, to the rapidity with which an appropriate therapy is initiated. However, a fast and specific test for diagnosis is a prerequisite for early initiation of treatment. The demonstration of Mycobacterium tuberculosis by culture of the cerebrospinal fluid (CSF) is a lengthy process, which delays the diagnosis; moreover, cultures may remain sterile even in cases proven at necropsy. ${ }^{2}$ Direct demonstration of tubercular antigens in CSF by radioimmunoassays (RIA), ${ }^{34}$ enzyme-linked immunosorbent assays (ELISA), ${ }^{56}$ and latex agglutination ${ }^{7}$ has been reported, but the sensitivities and specificities of these techniques have yet to be assessed. In addition, the presence of antimycobacterial antibodies and/or soluble immune complexes could mask such tubercular antigens. TM is indeed characterised by the intrathecal synthesis of oligoclonal $\mathrm{IgG}^{89}$ which, in one case, ${ }^{9}$ were proved to be directed against mycobacterial antigens. The detection of such anti-mycobacterial antibodies in the CSF by RIA or ELISA would be a useful adjunct for early diagnosis of TM. ${ }^{60-12}$

The antigen composition of $M$ tuberculosis is very complex. ${ }^{13}$ Some 30 antigens have been detected by a reference system based on crossed immunoelectrophoresis. ${ }^{14}$ The less mobile polymer in this system is antigen 60 (A60), which is the main thermostable immunogen of both "old tuberculin" and "purified protein derivative" (PPD), known reagents for cutaneous testing in tuberculosis. ${ }^{15}$ A60 was purified from the cytoplasm of $M$ bovis. ${ }^{16}$ It is a high molecular weight complex $\left(10^{6}-10^{7}\right.$ daltons) containing three moieties of free lipids, lipopolysaccharides and lipoproteins. ${ }^{17}$ This antigen is located in the bacterial cytosol during the exponential growth phase, accumulates in the walls of stationary cells, and is later released extracellularly. ${ }^{18}{ }^{19} \mathrm{~A} 60$ is a powerful immunogen inducing primary and secondary humoral responses and delayed hypersensitivity reactions when injected into mice. ${ }^{20}$ An A60-based ELISA-type immunoassay has been developed for serological analysis of tuberculosis in humans (Baelden et al, unpublished). The use of A60 as a new tuberculin for cutaneous testing has been proposed. ${ }^{21}$

In this study, an immunoblotting method 
Table 1 Clinical and biological data of patients with tuberculous meningitis

\begin{tabular}{|c|c|c|c|c|c|c|c|c|c|c|c|}
\hline \multirow{2}{*}{$\begin{array}{l}\text { Patient } \\
\text { number }\end{array}$} & \multirow{2}{*}{$\begin{array}{l}\text { Sex } \\
\text { Male/ } \\
\text { Female) }\end{array}$} & \multirow{2}{*}{$\begin{array}{l}\begin{array}{l}\text { Age } \\
\text { (years) }\end{array} \\
1\end{array}$} & \multicolumn{5}{|c|}{ First CSF analysis } & \multicolumn{2}{|c|}{$\begin{array}{l}\text { Microbiological analysis } \\
\text { of } C S F\end{array}$} & \multirow{2}{*}{$\begin{array}{l}\begin{array}{l}\text { Lung } \\
\text { tuberculosis }\end{array} \\
\begin{array}{l}\text { (Radiographic } \\
\text { analysis) }\end{array}\end{array}$} & \multirow{2}{*}{$\begin{array}{l}\text { Outcome } \\
\text { Death }\end{array}$} \\
\hline & & & $\begin{array}{l}\begin{array}{c}\text { Protein } \\
(\mathrm{mg} / \mathrm{dl})\end{array} \\
312\end{array}$ & \multicolumn{2}{|c|}{ Cells $/ \mathrm{mm}^{3}$} & \multicolumn{2}{|c|}{$\begin{array}{l}\text { Glucose } \\
\text { (mg/dl) (serum) }\end{array}$} & Staining & Culture & & \\
\hline $\begin{array}{l}1 \\
2 \\
3 \\
4 \\
5 \\
6 \\
7 \\
8\end{array}$ & $\begin{array}{l}F \\
M \\
F \\
F \\
F \\
M \\
F \\
F\end{array}$ & $\begin{array}{l}1 \\
17 \\
53 \\
14 \\
14 \\
13 \\
26 \\
50\end{array}$ & $\begin{array}{r}312 \\
122 \\
50 \\
23 \\
262 \\
5000 \\
220 \\
281\end{array}$ & $\begin{array}{r}106 \\
890 \\
800 \\
78 \\
900 \\
1000 \\
232 \\
455\end{array}$ & $\begin{array}{l}(10)^{\star} \\
(61) \\
(15) \\
(79) \\
(35) \\
(39) \\
(96) \\
(96)\end{array}$ & $\begin{array}{l}60 \\
29 \\
44 \\
67 \\
11 \\
41 \\
27 \\
15\end{array}$ & $\begin{array}{l}(104) \\
(82) \\
(89) \\
(98) \\
(72) \\
(88) \\
(74) \\
(78)\end{array}$ & $\begin{array}{l}- \\
\overline{-} \\
- \\
\overline{+} \\
\overline{+} \\
-\end{array}$ & $\begin{array}{l}+ \\
+ \\
+ \\
+ \\
+ \\
+ \\
- \\
-\end{array}$ & $\begin{array}{l}- \\
+ \\
+ \\
- \\
- \\
- \\
-\end{array}$ & $\begin{array}{l}\text { Death } \\
\text { Complete recovery } \\
\text { Complete recovery } \\
\text { Major sequelae† } \\
\text { Slight sequelae } \\
\text { Major sequelae } \\
\text { Complete recovery } \\
\text { Complete recovery }\end{array}$ \\
\hline
\end{tabular}

*Percentage of lymphocytes in total CSF cells.

† Major sequelae included hydrocephalus, bradypsychia, spastic paraparesis, and tardive syringomyelia.

tuberculosis. The youngest (patient 1) was infected by her grandmother and her sister also had lung tuberculosis. All patients had HIV seronegativity. Initial CSF analysis revealed pleocytosis (mostly lymphocytes) in all cases with high protein content in six and glucose levels below $40 \mathrm{mg} / \mathrm{dl}$ in 4 . The ZielhNeelsen staining was positive in one case and the cultures were positive for $M$ tuberculosis in six. Patient 1 died after being in a comatose state for six months. In the other cases the standard anti-tuberculous therapy led to a return to normal CSF values in cell number and glucose levels, although an alteration of the blood-brain barrier persisted in patients 4 and 6. Slight or major sequelae persisted in patients 4, 5 and 6; clinical recovery was complete in four patients $(2,3,7,8)$.

\section{Materials and methods Samples}

Twenty two CSF and serum paired samples were collected at various intervals from TM patients, up to sixty nine months after onset (table 2). After centrifugation, aliquots of $0.5-$ $2 \mathrm{ml}$ were kept frozen at $-20^{\circ} \mathrm{C}$. The total protein content of CSF was determined by nephelometry and albumin and IgG in both CSF and serum by immunonephelometry.

\section{Immunoblotting technique}

The technique used to identify anti-mycobacterial antibodies was similar to the immunoblotting procedure first described by Dörries and Ter Meulen, ${ }^{22}$ with slight modifications. ${ }^{23} 24$

Agarose gel plates were prepared with $0.36 \mathrm{~g}$ Isogel Agarose-EF for electrofocusing and $4.3 \mathrm{~g}$ sorbitol containing $2 \mathrm{ml}$ ampholine (pH range 3.5-9.5).

The nitrocellulose sheet was dipped overnight into either soluble mycobacterial antigens at a concentration of $300 \mu \mathrm{g} / \mathrm{ml}$ proteins (Lowry method) or A60 at the same protein concentration, and washed in Tris buffer saline (TBS, Tris $20 \mathrm{mM}, \mathrm{NaCl}$ $500 \mathrm{mM}, \mathrm{pH} 7.5)$ containing $0.1 \%$ Tween 20 (Technicon Diagnostics) for 60 minutes with three changes.

Table 2 Biological data of CSF and serum samples studied by immunoblotting

\begin{tabular}{|c|c|c|c|c|c|c|c|c|}
\hline \multirow{3}{*}{$\begin{array}{l}\text { Patient } \\
\text { number }\end{array}$} & \multirow{3}{*}{$\begin{array}{l}\text { Samples } \\
\text { number }\end{array}$} & \multirow[b]{3}{*}{ Time } & \multicolumn{4}{|c|}{ CSF analysis } & \multirow{2}{*}{\multicolumn{2}{|c|}{ Immunoblotting $\dagger$}} \\
\hline & & & \multirow{2}{*}{$\begin{array}{l}\text { Protein } \\
\text { (mg/dl.) }\end{array}$} & \multirow{2}{*}{$\begin{array}{l}\text { Glucose } \\
\text { (mg/dl) }\end{array}$} & \multirow{2}{*}{\multicolumn{2}{|c|}{ Cells $/ \mathrm{mm}^{3}$}} & & \\
\hline & & & & & & & $C S F$ & Serum \\
\hline 1 & $\begin{array}{l}1 \| \\
2 \\
3 \| \\
4 \| \\
5 \|\end{array}$ & $\begin{array}{l}12 \mathrm{~d} \\
15 \\
26 \\
41 \\
3 \mathrm{~m}\end{array}$ & $\begin{array}{r}26 \\
1900 \\
46 \\
95 \\
100\end{array}$ & $\begin{array}{l}52 \\
20 \\
76 \\
39 \\
66\end{array}$ & $\begin{array}{r}0 \\
176 \\
4 \\
1 \\
10\end{array}$ & $(95) \S$ & $\begin{array}{l}- \\
+ \\
+ \\
++ \\
+++\end{array}$ & $\begin{array}{l}- \\
- \\
\bar{t}+\end{array}$ \\
\hline 2 & $\begin{array}{r}6 \\
7 \\
8 \\
9 \\
10\end{array}$ & $\begin{array}{c}60 \mathrm{~d} \\
72 \\
85 \\
108 \\
12 \mathrm{~m}\end{array}$ & $\begin{array}{r}143 \\
185 \\
102 \\
109 \\
42\end{array}$ & $\begin{array}{l}14 \\
36 \\
52 \\
45 \\
62\end{array}$ & $\begin{array}{r}405 \\
323 \\
176 \\
125 \\
7\end{array}$ & $\begin{array}{l}(53) \\
(76) \\
(87) \\
(63)\end{array}$ & $\begin{array}{l}+ \\
+++ \\
+ \\
+ \\
-\end{array}$ & $\begin{array}{l}- \\
+ \\
- \\
-\end{array}$ \\
\hline 3 & $\begin{array}{l}11 \\
12\end{array}$ & $\begin{array}{l}22 \mathrm{~d} \\
31\end{array}$ & $\begin{array}{r}136 \\
96\end{array}$ & $\begin{array}{l}14 \\
69\end{array}$ & $\begin{array}{r}269 \\
1110\end{array}$ & $\begin{array}{l}(66) \\
(18)\end{array}$ & $\begin{array}{l}++ \\
+++\end{array}$ & $\begin{array}{l}+ \\
+\end{array}$ \\
\hline 4 & 13 & $69 m$ & 158 & 55 & 0 & & + & - \\
\hline 5 & 14 & 47d & 270 & 28 & 1197 & (30) & ++ & - \\
\hline 6 & $\begin{array}{l}15 \\
16 \\
17\end{array}$ & $\begin{array}{l}7 \mathrm{~m} \\
20 \\
34\end{array}$ & $\begin{array}{l}4200 \\
2400 \\
2600\end{array}$ & $\begin{array}{l}57 \\
56 \\
63\end{array}$ & $\begin{array}{r}83 \\
10 \\
7\end{array}$ & $\begin{array}{l}(99) \\
(96) \\
(97)\end{array}$ & $\begin{array}{l}+++ \\
++ \\
++\end{array}$ & $\begin{array}{l}+ \\
+ \\
-\end{array}$ \\
\hline 7 & $\begin{array}{l}18 \\
19 \\
20\end{array}$ & $\begin{array}{l}14 d \\
27 \\
76\end{array}$ & $\begin{array}{l}220 \\
170 \\
195\end{array}$ & $\begin{array}{l}29 \\
20 \\
43\end{array}$ & $\begin{array}{l}544 \\
232 \\
216\end{array}$ & $\begin{array}{l}(50) \\
(99) \\
(94)\end{array}$ & $\begin{array}{l}\overline{+}+ \\
+++\end{array}$ & $\begin{array}{l}- \\
++\end{array}$ \\
\hline 8 & $\begin{array}{l}21 \\
22\end{array}$ & $\begin{array}{l}4 \mathrm{~m} \\
7\end{array}$ & $\begin{array}{l}83 \\
44\end{array}$ & $\begin{array}{l}50 \\
53\end{array}$ & $\begin{array}{l}26 \\
10\end{array}$ & $\begin{array}{l}(88) \\
(99)\end{array}$ & $\begin{array}{l}++ \\
++\end{array}$ & - \\
\hline
\end{tabular}

*Time after the appearance of clinical symptoms, expressed in days (d) or months (m)

+ Paired samples of CSF and serum were tested at the same IgG concentration.

†Serum glucose levels varied between 68 and $125 \mathrm{mg} / \mathrm{dl}$.

$\S$ Percentage of lymphocytes in total CSF cells.

|Ventricular CSF. 
Figure 1 Immunoblots of anti-mycobacterial specific IgG from unconcentrated CSF and the

corresponding serum (SER) diluted to the same IgG concentration, after isoelectric focusing in agarose gel and transfer by immunoaffinity to sheets coated with total mycobacterial antigens. Samples 15, 16 and 17 from patient 6 (table 2) were collected seven, 20 and 34 months after onset of the disease, respectively. Staining of antimycobacterial oligoclonal antibodies is restricted to or more clearly marked in CSF than in the corresponding serum. The total amounts of $\mathrm{IgG}$ applied on the gel were for the three paired samples, 26,21 and $31 \mu \mathrm{g}$ respectively.

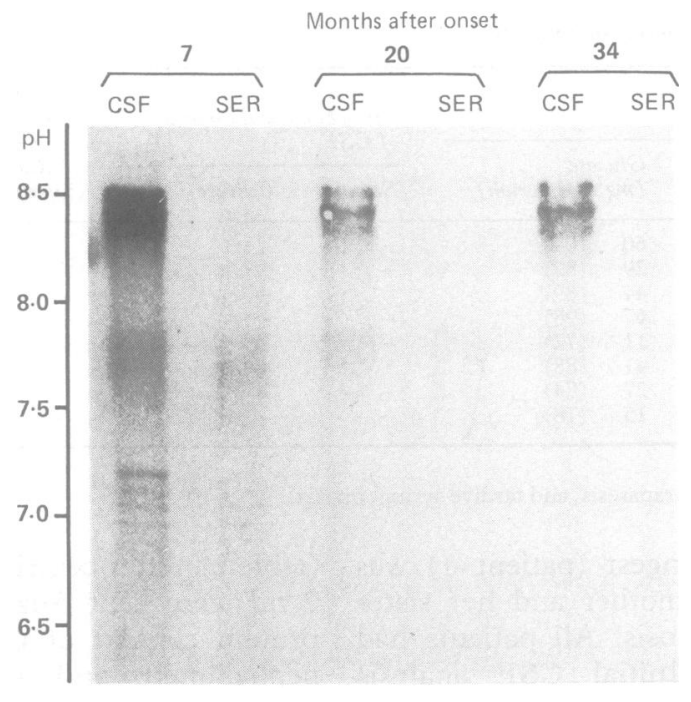

Each serum was diluted with distilled water to obtain an IgG concentration equal to that of the paired CSF sample. Ten $\mu \mathrm{l}$ of sera and CSF were then applied side by side and isoelectrically focused for 60 minutes at $10^{\circ} \mathrm{C}$ in a LKB Multiphor Unit. Unprecipitated proteins were removed by applying a filter paper moistened in PBS on the gel surface. Precipitated proteins were blotted onto the mycobacterial antigen-loaded nitrocellulose sheet under a uniform weight of $1 \mathrm{~kg}$ for 60 minutes at $10^{\circ} \mathrm{C}$. The immunoblot was then washed in TBS-Tween and incubated for 90 minutes at $20^{\circ} \mathrm{C}$ with biotinylated anti-human IgG antiserum (Dako Lot 016, Copenhagen, Denmark) diluted 20 -fold in TBS containing $0.3 \%$ bovine serum albumin (BSA, Calbiochem). After three 15 minute washings with TBS-Tween, the immunoblot was incubated with the streptavidin-biotin-peroxidase complex (Amersham, United Kingdom) diluted 400 -fold in TBS-BSA. Staining of the antigen-antibody bands by 4 chloro-1-naphthol (Biorad, United Kingdom) was performed by standard technique.

In addition the total IgG pattern of the focused samples was revealed by a similar immunoblotting procedure on nitrocellulose sheet coated with an anti-human IgG antiserum (Dako).

\section{Mycobacterial antigens}

A preparation of unfractionated cytoplasm antigens was obtained by ultrasonication (type B12 Branson Sonifier) of $M$ tuberculosis strain H 37 Ra (Difco Laboratories, Detroit, United States) suspended in Na phosphate buffer $0 \cdot 1$ $\mathrm{M}$, containing $0.15 \mathrm{M} \mathrm{NaCl}, \mathrm{pH} 7.6$ (PBS): the homogenate was centrifuged at $6,000 \mathrm{~g}$ for 15 minutes at $4^{\circ} \mathrm{C}$, the pellet was discarded and the supernatant stored at $-20^{\circ} \mathrm{C}$.

The mycobacterial antigen $\mathrm{A} 60$ was prepared from the cytoplasm of $M$ bovis BCG by exclusion gel chromatography on columns of Sepharose $6 \mathrm{~B} \cdot{ }^{16} \mathrm{~A} 60$ was identified by crossed immunoelectrophoresis according to a reference system $^{14}$ on $1 \%$ agarose gel slab using anti-BCG antiserum in the second dimension. A quantitative determination of A60 was made by spectrophotometric measurements of its polysaccharide and protein moieties. $^{16}$

\section{Results}

Oligoclonal anti-mycobacterial IgG antibodies restricted to, or more marked in the CSF than in the corresponding serum were detected in samples from the six patients with bacteriologically proven TM (table 2; figs 1,2 ), but also from the two patients with clinically suspected TM (fig 3, 4, lanes II A and B). In some cases, the oligoclonal bands were barely detectable on a background of polyclonal antibodies but in most cases, the oligoclonal pattern of these antibodies was very pronounced. As CSF and paired sera were tested at the same IgG concentration after appropriate dilutions, the far deeper staining seen in the CSF is an indication of an intrathecal synthesis of these antibodies. The occurrence of such a local synthesis was graded from 0 to +++ by visual inspection of the immunoblots (table 2 ). Uniformly negative results were obtained with samples from

Figure 2 Immunoblots of anti-mycobacterial specific IgG from unconcentrated CSF and the corresponding serum (SER) diluted to the same IgG concentration. The nitrocellulose sheets were coated with a crude preparation of cytoplasmic antigens of $M$ tuberculosis $H 37 R a(A)$, or with purified $A 60(B)$. Lane I: samples 20 from patient 7; lane II: samples 17 from patient 6 (table 2); lane III: control samples from a patient with herpetic meninigitis. The total amounts of $\operatorname{Ig} G$ applied on the gel were 2.3, 31 and $1 \cdot 2 \mu \mathrm{g}$ respectively.

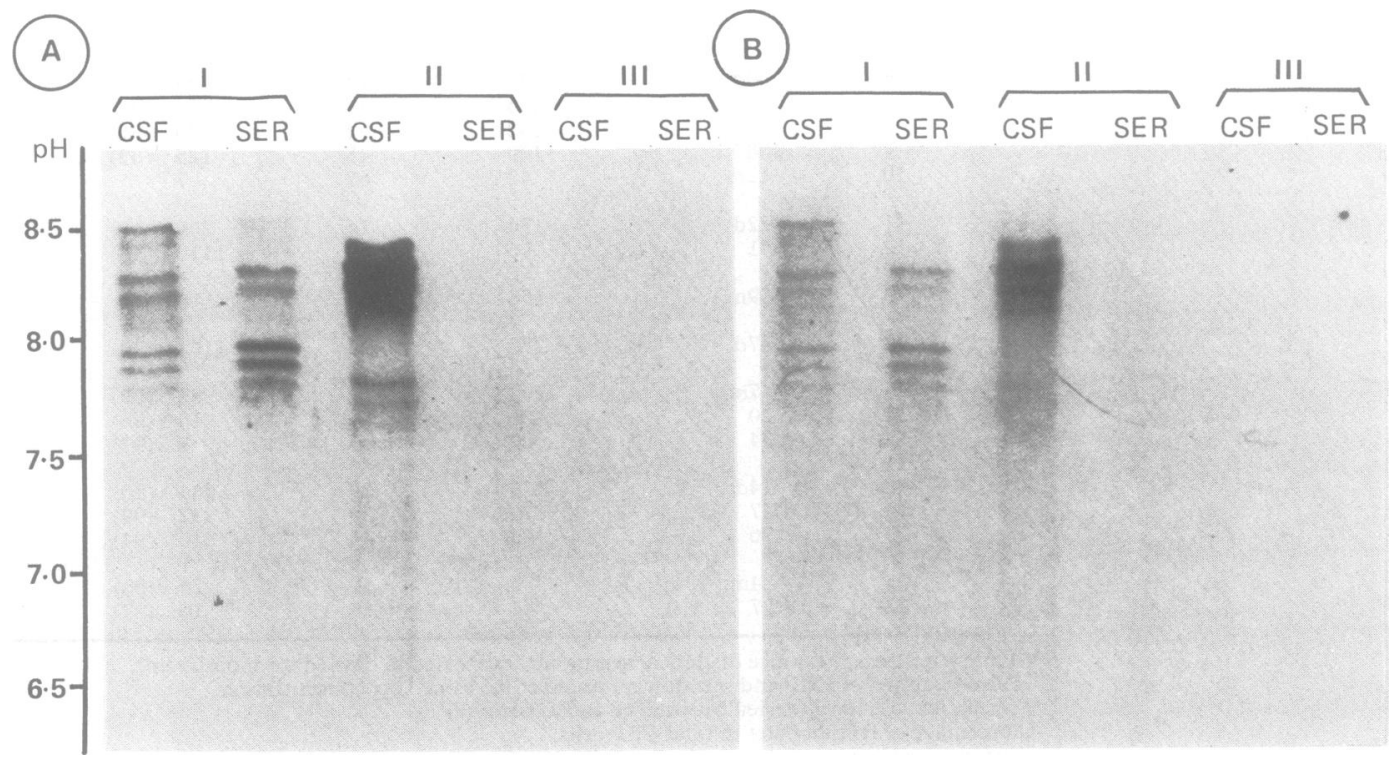


Figure 3 Immunoblots of IgG from unconcentrated CSF and the corresponding serum ( $S E R$ ) diluted to the same Ig $G$ concentration after isoelectric focusing in agarose gel and transfer by coated with total mycobacterial antigens. Samples 18, 19 and 20 from patient 7 (table 2 ) were collected at days 14, 27 and 76 after clinical onset of the disease and the total amounts of $\mathrm{IgG}$ 2.9 and $2.3 \mu \mathrm{g}$, respectively. No reaction was observed at day 14, whereas two oligoclona bands of specific antimycobacterial IgG were present in CSF, but not in the serum, at day 27. A similar oligoclonal pattern of specific antibodies, but with a staining intensity slightly different from one hand to another, was present in CSF and in serum at day 76. anti-mycobacterial specific immunoaffinity to sheets applied on the gel were 3.5,

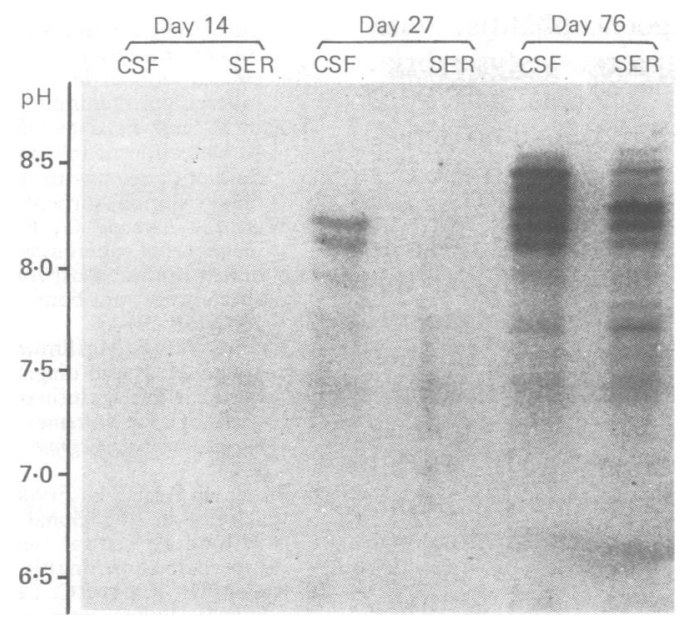

patients with tension headache (10), sciatica (10), multiple sclerosis (10), viral meningitis (10) or Borrelia burgdorferi meningoradiculitis (5) (fig 2, lane III).

Most samples under study were collected late in the course of the disease. The earliest samples which were collected 12 and 14 days after the appearance of clinical symptoms (1, patient 1 and 18, patient 7) were negative. However, samples collected at days 15 (2, patient 1), 22 (11, patient 3$)$ and $27(19$, patient 7 , fig 3), that is, at days 6,7 and 14 of admission to hospital, were already clearly positive. When serial samples were available, the staining intensity for specific antibodies generally increased with time and reached a peak one to three months after clinical onset. High levels of CSF anti-mycobacterial antibodies were observed in samples 13 (table 2) and 17 (fig 1) from patients 4 and 6: these samples were taken 69 and 34 months respectively, after onset. At this time these patients were considered cured of the tuberculous infection, but presented

Figure 4 Comparison of
all IgG (A: upper panel) all IgG ( $A$ : upper panel and anti-mycobacterial specific IgG ( $B$ : lower panel) in CSF and serum (SER) of TM patients. In lanes I (sample 20, patient 7), the asterisk indicates a CSF-restricted Ig $G$ band with no detectable antimycobacterial antibody specificity. In contrast, numerous oligoclonal antimycobacterial IgG bands were visualised from the polyclonal background of IgG. In lanes II $A$ and II $B$ (samples 21 and 22 , patient 8) arrows indicate CSF oligoclonal IgG bands with anti-

mycobacterial activity (for one band, lane IIb, this activity was only detectable by visual inspection on the immunoblot). The total amounts of IgG applied to the gel were $0.05 \mu \mathrm{g}$ for all samples in the upper panel; in the lower panel these amounts were $2 \cdot 3 \mu \mathrm{g}$ in lane $I, 0.69 \mu \mathrm{g}$ in lane II $A$ and $0.3 \mu \mathrm{g}$ in lane IIB.

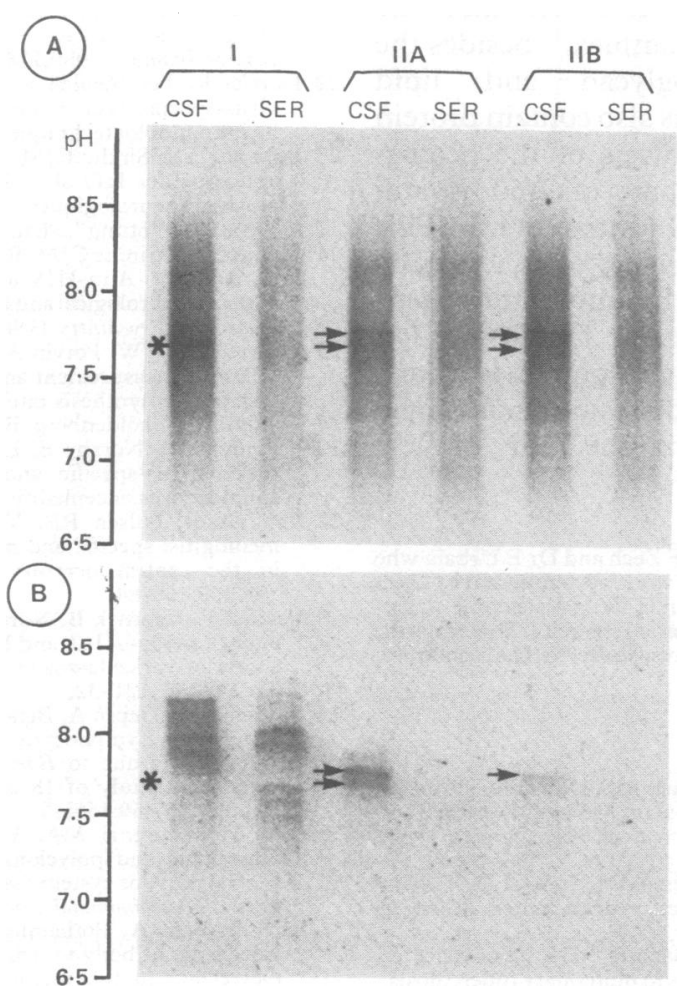

severe permanent sequelae (therapy was stopped after 18 months). Although an alteration of the permeability of the blood-CSF barrier to plasma proteins was evident in both cases and was likely due to persistent foci of arachnoiditis, glucose level and cell number in the CSF were normal. Intra-thecal synthesis of anti-mycobacterial antibodies, however, was no longer detectable in sample 10 which was taken from patient 2 (table 2 ), after 12 months of successful treatment.

Similar immunoblotting patterns were obtained when antigen A60 was used for coating the nitrocellulose sheet (fig $2 \mathrm{~B}$ ) in place of a whole mycobacterial homogenate (fig $2 \mathrm{~A}$ ). Indeed, the same oligoclonal IgG bands were detected at the same isoelectric points with similar intensity of staining.

When the complete IgG pattern was compared with that of anti-mycobacterial antibodies (fig 4), it was noted that some IgG bands were not directed against mycobacterial antigens (fig 4, lane I). In addition, it was possible to detect oligoclonal anti-mycobacterial IgG antibodies from the polyclonal background of IgG in CSF as well as in the corresponding serum. The failure therefore to detect oligoclonal IgG bands did not exclude the presence of oligoclonal anti-mycobacterial antibodies.

\section{Discussion}

In normal conditions, CSF IgG originate from blood as demonstrated by studies in humans with radiolabelled $\mathrm{IgG}^{25}$ Consequently, the relative amounts of IgG antibodies directed against a given antigen should be identical in both fluids even in the case of an altered bloodCSF barrier. In contrast, when immune reactions occur within the central nervous system, the proportion of locally produced antibodies will be higher in CSF than in serum. In our study since paired CSF and serum samples were tested at the same IgG concentration, the results of the immunoblots of both fluids can be directly compared.

With this technique, we were able to detect a local synthesis of antimycobacterial antibodies in all of the patients with bacteriologically proven or clinically suspected TM. In the two cases with negative cultures positive immunoblotting tests were a valid and the sole biological confirmation of a clinical diagnosis of TM.

Polyclonal and/or oligoclonal anti-mycobacterial specific IgG were detected in samples collected 15 to 27 days after the clinical onset of meningitis. Since cultures of $M$ tuberculosis from CSF samples may yield visible colonies only after six weeks and may also remain sterile even in cases that have been proved at necropsy, ${ }^{2}$ the demonstration of the intrathecal synthesis of anti-mycobacterial antibodies appears to be a useful tool for diagnosis of TM. Our data indicate that the synthesis of these antibodies may persist for several years (see late samples from patients 4 and 6 , who were considered cured after a standard 18 months treatment).

It should be noted that these two patients 
presented severe meningoencephalitis, with major sequelae (paraplegia, dysarthria, intellectuel impairment), whereas patient 2 (who has completely recovered), had no detectable intrathecal synthesis of IgG antibodies one year after the clinical onset of the disease. The long-lasting intrathecal synthesis of antimycobacterial antibodies might be due to the persistence of possibly unviable $M$ tuberculosis within the central nervous system. Another possibility is that immunoregulatory mechanisms for antibody synthesis fail to suppress proliferation and differentiation of B-cell clones after their activation within the brain. Persistence of intrathecal production of antibodies over long periods of time, as long as eight years, has also been reported in other infectious diseases of the nervous system, such as herpetic encephalitis, ${ }^{26}$ mumps meningitis ${ }^{27}$ and varicella-zoster meningoencephalitis. ${ }^{28}$ In contrast, we have observed the spontaneous disappearance of anti- $B$ burgdorferi oligoclonal IgG in some patients recovering from meningoradiculitis. $^{29}$

The presence of some oligoclonal IgG bands restricted to the CSF but devoid of detectable anti-mycobacterial antibody specificity is possibly due to non-specific polyclonal B-cell activation. The intrathecal production of antibodies to unrelated agents was observed in patients with herpetic encephalitis or mumps meningitis. ${ }^{26} 270$ Another explanation could be that our antigen preparations do not contain sufficient amounts of a minor, but highly immunogenic epitope to obtain a transfer by immunoaffinity on the nitrocellulose sheet.

The fact that the immunoblotting patterns with A60 were similar to those with whole mycobacterial homogenates suggests that most of the intrathecally synthesised IgG in the case of TM were specifically directed against the former antigen.

It should be noted, however, that the structure of $A 60$ is very complex: ${ }^{.7}$ besides the lipoglucan, lipopeptidoglycan and lipid moieties, A60 preparations also contain protein components. After hydrolysis of the protein moiety, the lipoglycan part of $\mathrm{A} 60$ is still reactive with anti-BCG antiserum. ${ }^{17}$ This indicates that both protein and polysaccharide moieties are responsible for the immunogenicity of the antigen. A recent ELISA study ${ }^{31}$ showed that IgG antibody responses to both a 14-kilodalton protein and lipoarabinomannan were immunodominant in the CSF of TM patients.

We thank Professor P Evrard, Dr F Zech and Dr E Urbain who referred patients $1,6,7$ and 8 . This work was supported by grant number 3-4529-79 from the "Fonds de la Recherche Scien"Ministère de la Communauté Française-Recherche Appliquée.

1 Clark WC, Metcalf JC, Muhlbauer MS, Dohan FC, Robertson JH. Mycobacterium tuberculosis Meningitis: a report of twelve cases and a literature review. Neurosurgery 1986; 18:604-10.

2 Ogawa SK, Smith MA, Brennessel DJ, Lowy FD. Tuberculous meningitis in an urban medical center. Medicine 1987;66:317-26.

3 Samuel AM, Ashtekar MD, Ganatra RD. Significance of circulating immune complexes in pulmonary tuberculosis. Clin Exp Immunol 1984;58:317-24.
4 Kadival GV, Samuel AM, Mazarelo TBMS, Chaparas SD, Radioimmunoassay for detecting Mycobacterium tuberculosis antigen in cerebrospinal fluids of patients with tuberculous meningitis. J Inf Dis 1987;155:608-11.

5 Sada E, Ruiz-Palacios GM, Lopez-Vidal Y, Ponce de Leon $S$. Detection of mycobacterial antigens in cerebrospinal fluid of patients with tuberculous meningitis by enzymelinked immunosorbent assay. Lancet 1983;ii:651-2.

6 Watt G, Zaraspe G, Bautista S, Laughlin LW. Rapid diagnosis of tuberculous meningitis by using an enzymediagnosis of tuberculous meningitis by using an enzyme-
linked immunosorbent assay to detect mycobacterial antigen and antibody in cerebrospinal fluid. J Inf Dis 1988;158:681-6.

7 Krambovitis E, McIllmurray MB, Lock PE, Hendrickse W, Holzel $H$. Rapid diagnosis of tuberculous meningitis by latex particle agglutination. Lancet 1984;ii:1229-31.

8 Laterre EC. Les protéines du liquide céphalo-rachidien à l'état normal et pathologique. (Thesis) Arscia-Maloine, Paris, 1965.

9 Kinnman J, Link H, Fryden A. Characterization of antibody activity in oligoclonal Immunoglobulin $G$ synthesized within the central nervous system in a patient with within the central nervous system in a patient with
tuberculous meningitis. J Clin Microbiol 1981;13:30-5.

10 Kalish SB, Radin RC, Levitz D, Zeiss CR, Phair JP. The enzyme-linked immunosorbent assay method for IgG antibody to Purified Protein derivative in Cerebrospinal antibody to Purified Protein derivative in Cerebrospinal
fluid of patients with tuberculous meningitis. Ann Int Med 1983;99:630-3.

11 Chandramuki A, Allen PRJ, Keen M, Ivanyi J. Detection of mycobacterial antigen and antibodies in the cerebrospinal fluid of patients with tuberculous meningitis. J Med Microbiol 1985;20:239-47.

12 Ashtekar MD, Dhalla AS, Mazarello TBMS, Samuel AM. A study of Mycobacterium tuberculosis Antigen and Antibody in Cerebrospinal Fluid and Blood in Tuberculous Meningitis. Clin Immunol Immunopath 1987;

3 Daniel TM, Janicki BW. Mycobacterial antigens: a review of their isolation, chemistry and immunological properties. Microbiol Revs 1978;42:84-113.

14 Closs O, Harboe M, Axelsen NH, Bunch-Christensen K, Magnusson $M$. The antigens of Mycobacterium bovis strain BCG studied by crossed immunoelectrophoresis: a reference system. Scand J Immunol 1980;12:249-63.

15 Harboe M. Antigens of PPD, old tuberculin and autoclaved Mycobacterium bovis BCG studied by crossed immunoelectrophoresis. Am Rev Respir Dis 1981;124:80-7.

16 Cocito C, Vanlinden F. Preparation and properties of antigen 60 from Mycobacterium bovis BCG. Clin Exp Immunol 1986;66:262-72.

17 Fabre I, L'Homme O, Bruneteau M, Michel G, Cocito C. Chemical composition of antigen 60 from Mycobacterium bovis BCG. Scand J Immunol 1986;24:591-602.

18 Cocito C, Vanlinden F. Subcellular localisation and sedimentation behaviour of antigen 60 from Mycobactsedimentation behaviour of antigen 60 from Mycobact-

19 Cocito C, Vanlinden F. Metabolism of the TMA group of antigens during the growth cycle of mycobacteria. Med Microb Immunol 1988b;177:357-67.

20 Cocito C, Baelden MC, Benoit C. Immunological properties of antigen 60 of BCG: Induction of humoral and cellular immunity reactions. Scand J Immunol 1987;25:579-85.

21 Benoit CH, Beschin A, Desmecht M, Dekeyser P, Cocito C. Delayed hypersensitivity reactions by the mycobacterial antigen A60 and cutaneous testing in tuberculosis. Med Microb Immunol 1989;178:105-12.

22 Dorries R, Ter Meulen V. Detection and identification of virus-specific IgG in unconcentrated cerebrospinal fluid virus-specific lgG in unconcentrated cerebrospinal fluid

23 Bukasa KSS, Sindic CJM, Limet JN, Laterre C. Activité anticorps des IgG oligoclonales du LCR dans les pathologies neurologiques infectieuses. Détection pa "Immunoblotting". Acta Neurol Belg 1988;88:203-20.

24 Bukasa KSS, Sindic CJM, Bodeus M, Burtonboy G, Laterre C, Sonnet J. Anti-HIV antibodies in the CSF of AIDS patients: a serological and immunoblotting study. J Neurol Neurosurg Psychiatry 1988;51:1063-8.

25 Tourtellotte WW, Potvin AR, Fleming JO, et al. Multiple sclerosis: measurement and validation of central nervous system IgG synthesis rate. Neurology 1980;30:240-4.

26 Vandvik B, Sköldenberg B, Forsgren M, Stiernstedt G, Jeansson S, Norrby E. Long-term persistence of intrathecal virus-specific antibody responses after herpes simplex virus encephalitis. J Neurol 1985;231:307-12.

27 Vandvik B, Nilsen RE, Vartdal F, Norrby E. Mumps meningitis: specific and non-specific antibody responses meningitis: specific and non-specific antibody responses
in the central nervous system. Acta Neurol Scand in the central

28 Vartdal F, Vandvik B, Norrby E. Intrathecal synthesis of oligoclonal IgG, IgA and IgM virus-specific antibodies in a case of varicella-zoster meningoencephalitis. $J$ Neurol Sci 1982;57:121-32.

29 Sindic CJM, Depré A, Bigaignon G, Goubau PF, Hella P, Laterre C. Lymphocytic meningoradiculitis and encep halomyelitis due to Borrelia burgdorferi: a clinical and serological study of 18 cases. J Neurol Neurosurg Psychiatry 1987;50:1565-71.

30 Link H, Laurenzi MA, Fryden A. Viral antibodies in oligoclonal and polyclonal IgG synthesized within the central nervous system over the course of mumps menin gitis. $J$ Neuroimmunol 1981;1:287-98.

31 Chandramuki A, Bothamley GH, Brennan PJ, Ivanyi J. Levels of antibody to defined antigens of Mycobacterium tuberculosis in tuberculous meningitis J Clin Microbiol 1989;821-5. 